\title{
Infectious disease risks from dead bodies following natural disasters
}

\author{
Oliver Morgan ${ }^{1}$
}

Suggested citation

Morgan O. Infectious disease risks from dead bodies following natural disasters. Rev Panam Salud Publica. 2004;15(5):307-12.

\begin{abstract}
Objective. To review existing literature to assess the risks of infection from dead bodies after a natural disaster occurs, including who is most at risk, what precautions should be taken, and how to safely dispose of the bodies.

Methods. Disease transmission requires the presence of an infectious agent, exposure to that agent, and a susceptible host. These elements were considered to characterize the infectious disease risk from dead bodies. Using the PubMed on-line databases of the National Library of Medicine of the United States of America, searching was done for relevant literature on the infection risks for public safety workers and funeral workers as well as for guidelines for the management of the dead and prevention of infection. A small but significant literature was also reviewed regarding the disposal of the dead and the contamination of groundwater by cemeteries. Results. Victims of natural disasters usually die from trauma and are unlikely to have acute or "epidemic-causing" infections. This indicates that the risk that dead bodies pose for the public is extremely small. However, persons who are involved in close contact with the dead-such as military personnel, rescue workers, volunteers, and others-may be exposed to chronic infectious hazards, including hepatitis B virus, hepatitis C virus, HIV, enteric pathogens, and Mycobacterium tuberculosis. Suitable precautions for these persons include training, use of body bags and disposable gloves, good hygiene practice, and vaccination for hepatitis $B$ and tuberculosis. Disposal of bodies should respect local custom and practice where possible. When there are large numbers of victims, burial is likely to be the most appropriate method of disposal. There is little evidence of microbiological contamination of groundwater from burial.

Conclusions. Concern that dead bodies are infectious can be considered a "natural" reaction by persons wanting to protect themselves from disease. However, clear information about the risks is needed so that responsible local authorities ensure that the bodies of disaster victims are handled appropriately and with due respect. This paper provides a source of information for those who are in the unfortunate position of managing those bodies.
\end{abstract}

Key words Natural disasters, disaster planning, cadaver, disease outbreaks, guidelines.

Following natural disasters, there is often concern that the bodies of victims

\footnotetext{
1 London School of Hygiene and Tropical Medicine, Public and Environmental Health Research Unit, London, United Kingdom. Send correspondence to: Oliver Morgan, London School of Hygiene and Tropical Medicine, Public and Environmental Health Research Unit, London WC1E 7HT, United Kingdom; email omorgan@bigfoot.com
}

can cause epidemics amongst surviving populations $(1,2)$. This sometimes leads to inappropriate burial of the dead without proper identification of the victims. Recent examples of such disasters include Hurricane Mitch in Central America in 1998; a cyclone in Orissa, India, in 1999; and earthquakes in El Salvador in 2001 and in Turkey in 2003. Although empirical evidence suggests otherwise (2), strong aversion to the dead may represent a "natural" instinct to protect ourselves against disease (3). Following large natural disasters, these instinctive uncertainties are compounded by the lack of clear information about how to manage the dead, and these uncertainties result in 
confusion among humanitarian workers, health organizations, and government authorities. Many individuals and organizations are still unclear about what the infectious risks associated with dead bodies really are, who is most at risk, what precautions should be taken, and how to safely dispose of the bodies. This paper reviews the risks for both the general public and for those who may be more intimately involved in managing the dead. The article also addresses the infectious disease risks associated with the disposal of the dead, an area that often causes particular problems.

Relevant literature was identified from the PubMed on-line database of the National Library of Medicine of the United States of America. Key words included "relief work," "disaster planning," "natural disasters," "disease outbreaks," "emergency medicine," "mortuary practice," "burial," and "cadaver." Bibliographies of all relevant papers were searched to identify further papers. Studies were selected if they addressed the handling and disposal of dead bodies.

\section{HOW INFECTIOUS ARE DEAD BODIES?}

Transmission of infection requires the presence of an infectious agent, exposure to that agent, and a susceptible host. It is therefore possible to characterize the infectious risks from dead bodies following a natural disaster by considering these elements. This section considers the presence of infectious agents in cadavers; the following sections make estimates of exposure.

The human body is host to many organisms, only some of which are pathogenic. When the body dies, the environment in which pathogens live can no longer sustain them. However, this does not happen immediately, and transmission of infectious agents from a cadaver to a living person may occur. Infectious hazards for individuals who routinely handle cadavers include tuberculosis, group A streptococcal infection, gastroenteritis, transmissible spongiform encephalop- athies (such as Creutzfeldt-Jakob disease), hepatitis B, hepatitis C, HIV infection, and possibly meningitis and septicemia (especially meningococcal) (4). Microorganisms involved in the decay process (putrefaction) are not pathogenic (5).

Do victims of natural disasters have these infections when they die? Usually disaster victims die from trauma, burns, or drowning $(2,6)$, and they are no more likely than the local population to have acute infections (meningitis and septicemia) or rare diseases (e.g., Creutzfeldt-Jakob disease). Instead, where disease is present, it is far more likely to be due to chronic infections with bloodborne viruses (hepatitis $B$ virus, hepatitis $C$ virus, and HIV), enteric pathogens, and possibly Mycobacterium tuberculosis (Table 1).

\section{RISK TO THE GENERAL PUBLIC}

Historically, epidemics resulting in mass casualties have only occurred from a few diseases, including plague, cholera, typhoid, tuberculosis, anthrax, and smallpox (2). As previously noted, such infections are no more likely to be present in disaster victims than in the general population. Furthermore, although some of these diseases are highly contagious, their causative agents are unable to survive long in the human body following death (4). It is therefore unlikely that such epidemics will result from contact with a cadaver. Indeed, survivors present a much more important reservoir for disease (2). Where dead bodies have contaminated water supplies, gastroenteritis has been the most notable problem (7), although communities will rarely use a water supply where they know it to be contaminated by dead bodies.

\section{HANDLING THE DEAD}

The occupational risks for pathologists and mortuary staff who routinely work with dead bodies are well known, and the risks are unlikely to be different for persons who are dealing with victims of a natural disaster.
TABLE 1. General categories and specific examples of infectious hazards associated with dead bodies after a natural disaster occurs

\begin{tabular}{l}
\hline \multicolumn{1}{c}{ Category/examples } \\
\hline Bloodborne \\
Hepatitis B \\
Hepatitis C \\
HIV \\
Gastrointestinal \\
Rotavirus diarrhea \\
Campylobacter enteritis \\
Salmonellosis \\
Enteric fevers (typhoid and paratyphoid) \\
Escherichia coli \\
Hepatitis A \\
Shigellosis \\
Cholera \\
Respiratory \\
Tuberculosis \\
\hline
\end{tabular}

However, incidents with a large number of fatalities may require a temporary workforce for the collection, transportation, storage, and disposal of the dead. These workers may include military personnel, rescue workers, volunteers, and others who have little or no experience in handling the deceased. Although there is no published literature about the risk of infections for this group, the risk is probably similar to that of public safety workers (e.g., emergency medical personnel, firefighters, and police officers) and funeral workers who are occupationally exposed to infectious agents during the intimate management of cadavers $(4,8-11)$. As noted above, the most likely type of infections are those produced by bloodborne viruses, enteric pathogens, and Mycobacterium tuberculosis.

\section{Bloodborne viruses}

The risk of infection from bloodborne viruses depends on the infection status of the victim (similar to the general population), likelihood and mode of exposure, and, in the case of hepatitis $B$, the vaccination status of the exposed individual. In many developing countries, especially in sub-Saharan Africa, Southeast Asia, the Middle East, the Pacific, and some countries in Latin 
America, the prevalence of chronic hepatitis B infection is around $8 \%$ to $10 \%$ (12). Hepatitis C virus is estimated to infect about $3 \%$ of the world's population, with prevalence being highest in Africa (5.3\%), the Eastern Mediterranean $(4.6 \%)$, the Western Pacific (3.9\%), and Southeast Asia (2.2\%); the prevalence is lowest in the Americas $(1.7 \%)$ and Europe (1.0\%) (13). The prevalence of HIV infection in those $14-45$ years old is as high as $30 \%$ to $40 \%$ in some African countries; about $0.1 \%$ in Asia, Eastern Europe, and Western Europe; and between $0.1 \%$ and $6 \%$ in Latin America and the Caribbean (14).

Exposure to bloodborne viruses can occur due to direct contact with nonintact skin, percutaneous injury from bone fragments and needles, and mucous membrane exposure from splashes of blood or body fluid to the eyes, nose, or mouth (10). Following one needle-stick injury from an infected individual, the risks of infection have been estimated to be: for hepatitis $\mathrm{B}$, between $6 \%$ and $30 \%$ in those who have had no prior hepatitis $B$ vaccination (15); for hepatitis C, $1.8 \%$ (9); and for HIV infection, $0.5 \%$ (14). Infection from nonintact skin or mucous membrane exposure is likely to be much lower $(9,15)$. Importantly, infectious HIV can survive in cadavers for a considerable amount of time (up to 16 days after death if stored at $2{ }^{\circ} \mathrm{C}$ ), and viable HIV has also been isolated from bone fragments, spleen, brain, bone marrow, and lymph nodes at autopsy 6 days postmortem (16).

\section{Gastrointestinal infections}

Because a corpse will commonly leak feces, persons handling dead bodies are more likely to be exposed to gastrointestinal organisms than to bloodborne viruses (4). Workers may be exposed through direct contact with the victim's body and soiled clothes, and transmission can occur via the fecal-oral route. Contamination of other equipment, such as stretchers and vehicles used for transportation or storage, is also possible. However, common gastrointestinal organisms do not survive long in the environment and present little risk of infection where the body has been decaying for some time, or has been in the water (4).

\section{Tuberculosis}

Around $1 \%$ of the world population is infected by tuberculosis each year. Rates are generally much higher in developing countries, especially Africa and Asia, and the increase in HIV infections has led to an increase in the prevalence of tuberculosis (17). A national study of tuberculosis in the United States of America found that funeral home directors had higher tuberculosis morbidity (standardized morbidity ratio, 3.9; 95\% confidence interval (CI), 2.2 to 6.3) (18) and higher tuberculosis mortality (proportionate morality ratio, 299; 95\% CI, 82 to 766 ) (19). This suggests that even when the chest cavity is not opened up, handling intact cadavers presents an increased risk of tuberculosis. Exposure may occur from gurgling at the nose and mouth of the cadaver due to fluid buildup in the chest cavity and putrefaction of tissues and organs (11). Also, residual air in the deceased's lungs may be exhaled when the body is moved (11). However, funeral workers have repeated occupational exposures to tuberculosis (11) and so may experience greater risk than is true with the one-time exposure experienced by those handling bodies after a disaster. On the other hand, storage of many cadavers together in temporary mortuaries may present an increased risk of infection; once aerosolized, the tubercle bacilli may remain viable for extended periods of time (20). The risk of tuberculosis may be reduced by placing a cloth over the deceased's mouth when moving the body (4) and by ensuring suitable ventilation where large numbers of bodies are stored (20).

\section{Reducing the risk of infection}

A number of simple measures can be taken to reduce the risk of infection associated with handling dead bodies.
Considering that some of the persons doing this work may not have had experience in handling the dead, some basic instruction about the risks and precautions may be required. Universal precautions for blood and body fluids and enteric precautions should be followed (15). When handling dead bodies, workers should wear gloves, especially if the bodies are badly damaged. Used gloves should be removed and kept in a suitable bag and disposed of appropriately (15). Where nondisposable gloves are used, they should be cleaned and disinfected (15). To avoid cross-contamination, personal items should not be handled while wearing soiled gloves, and a new pair is recommended after each body or group of bodies is handled (15). Other personal protective equipment, such as eyewear, gowns, and masks, are only required where large quantities or splashes of blood are anticipated (15) and are probably not necessary when handling bodies following a natural disaster. Hands should be washed after handling cadavers and before eating, and all equipment, including clothes, stretchers, and vehicles used for transportation, should be washed carefully with a disinfectant (15). Body bags will further reduce the risk of infection and are useful for the transport of cadavers that have been badly damaged. However, body bags reduce the rate of cooling of the cadaver, thus increasing the rate of decomposition, especially in hot climates $(4,21)$. Hepatitis B vaccination will help prevent infection and will be $70 \%$ to $80 \%$ effective within one week of exposure (9). Those with prior BCG vaccination may have some protection against tuberculosis, and tuberculin testing may be an appropriate follow-up measure.

\section{DISPOSAL OF DEAD BODIES}

There is often considerable concern about the disposal of the dead following a natural disaster. Putrefaction starts soon after death (22), and suitable storage facilities may not be available for a large number of remains 
(23). Concerns about the infectiousness of human remains and the unpleasantness of decaying bodies may lead to rapid unplanned disposal of the dead, sometimes before proper identification of the victim has been made. Concerns about disease may also lead to unnecessary "precautions" such as burying the deceased in common graves and adding chlorinated lime as a "disinfectant" (5).

\section{Cremation}

In normal circumstances, human remains are usually buried or cremated. Although cremation will render any remains noninfectious (24), special equipment and large quantities of fuel are required to achieve high enough temperatures (around $650{ }^{\circ} \mathrm{C}$ ) for sufficient lengths of time (usually 2.5-3 hours) for complete burning (24). This makes cremation less practical following mass casualty disasters. Furthermore, cremation should be avoided where victims have not been identified, in which case burial is a more practical option, allowing future disinterment of remains.

\section{Burial}

Burial of human remains can be thought of as a particular kind of landfill (25), similar to that of unlined "dilute and disperse" municipal waste landfill sites (26). A few studies of cemeteries have detected traceable plumes of indicator bacteria, suggesting that microbiological decay products reach the groundwater (25). While the pathways and composition of decay products are complex, the principal mechanism of contamination is by rainwater percolating through the soil and coming into contact with buried remains (27).

The soil in the unsaturated zone (above the water table) is the main line of defense against rainwater leaching from the grave into the groundwater. Pathogens are retained in the unsaturated soil zone, principally due to fil- tration and adherence to clay particles. Pathogen retention is greater in soils with high clay content but less in soil with a high water content and $\mathrm{pH}$ above 7 (28). Pathogens retained in the soil will eventually die off due to lack of nutrients, and die-off increases with reduced soil moisture, increased temperature (die-off rates double with every $10{ }^{\circ} \mathrm{C}$ ), and soil $\mathrm{pH}$ outside the range of 6 to 7 (28).

In a grave site, the disturbed nature of the soil provides an aerated environment that promotes rapid aerobic decomposition (29). However, it also attracts water, which leads to wetness at grave level, even in otherwise dry areas (25). Although this favors pathogen survival, decomposition of buried remains produces heat and alkaline soil conditions (30), possibly increasing pathogen die-off (28). However, the rate of heat production is highly dependent on burial depth, with significant temperature increases occurring within just a few days after burial at $0.3 \mathrm{~m}$, but taking several weeks at greater depths (1.2 m) (25). While probably similar, it is not clear how the decay and dispersion characteristics may differ where many people are buried simultaneously or where they are buried in communal graves.

Studies of cemetery groundwaters in Australia (25), Brazil ${ }^{2}$ (31), and the United States $(32,33)$ have all found evidence of contamination by organic products that are mostly associated with the decay process. No fecal coliforms were found, but pathogenic Pseudomonas aeruginosa, streptococci, and clostridia organisms were found in some samples $(24,30)$. However, only one study assessed the quality of groundwater outside the cemetery. That study found that microbiological indicator organisms attenuated rapidly with distance and that the decay plume was better characterized by

\footnotetext{
Matos BA, Pacheco A. Ocorrência de microrganismos no aqüífero freático do Cemitério Vila Nova Cachoeirinha, São Paulo. Joint World Conference on Groundwater. 31st August 2000, Fortaleza, Brazil.
}

products associated with the burial process (e.g., coffin materials and embalming substances) (25).

\section{Recommendations for burial}

Although there is some evidence of microbiological contamination in the immediate vicinity of cemeteries, the rapid attenuation of these microorganisms suggests that they pose little risk to the public (27). However, where it is necessary to choose a new burial site, several issues should be considered. A soil of sand-clay mix of low porosity and a small- to fine-grain texture is likely to maximize pathogen retention in the unsaturated zone (27). In such soil conditions, the water table should be at least $2.5 \mathrm{~m}$ deep in order to allow a "traditional" grave depth of six feet $(1.8 \mathrm{~m})$, with a $0.7-\mathrm{m}$ unsaturated zone (34). This may have to be adjusted for more porous soil conditions, topographic lows, and low points of hydraulic gradients (25). To protect water supplies, distances of at least 30 $\mathrm{m}$ from springs or watercourses and $250 \mathrm{~m}$ from any well, borehole, or any source of drinking water have been suggested (27). However, there are no accepted standards, and distances are best chosen based on local hydrogeological conditions and with the agreement of nearby communities. It may also be likely that following a flood event, soils may be saturated and the water table may be unusually high, making location of a suitable site more difficult.

\section{CONCLUSIONS}

There is no evidence that, following a natural disaster, dead bodies pose a risk of epidemics. "Epidemic-causing" acute diseases are unlikely to be more common among disaster victims than among the general population, suggesting that the risk to the general public is negligible. The same is true with casualties of conventional war (as distinct from biological, chemical, or radiological warfare). In both cases it 
is far more likely that survivors will be a source of disease outbreaks. However, those who handle victims may be exposed to chronic hazards such as bloodborne viruses, gastrointestinal infections, and tuberculosis. The risk for this group can be estimated from the disease prevalence in the local population and the likelihood of exposure and transmission.

Simple measures, such as handwashing and basic hygiene, can reduce the risk of such "occupational" exposures (Table 2). Those who are likely to be given the task of managing the dead (police, civil defense, military) would benefit from basic instruction as part of disaster preparedness activities. Access to suitable equipment (gloves, body bags, etc.) should also be considered. Following a catastrophic disaster or an event in a remote region, people with no previous instruction may be called upon to assist. Basic messages about suitable precautions
TABLE 2. Recommendations for managing the dead following natural disasters

\section{Suggested measures}

Universal precautions for blood and body fluids

Disposal or disinfection of used gloves

Avoiding cross-contamination of personal items

Washing hands after handling bodies and before eating

Disinfection of vehicles and equipment

Use of body bags, especially for badly damaged bodies

Hepatitis $B$ vaccination

No special arrangements, such as disinfection, with disposal of bodies

New burial areas sited at least $250 \mathrm{~m}$ away from drinking water sources, and with at least $0.7 \mathrm{~m}$ of distance above the saturated zone

(Table 2) would support local authorities and agencies who may themselves be unsure of appropriate methods. Where possible, disposal of the dead should be done according to local cus- tom and practice. Burial is the preferred option in the case of mass casualties and where victims cannot be identified. Burial is unlikely to cause contamination of groundwater if sited correctly (Table 2).

After natural disasters it is important that misinformation about the infectious disease risks of dead bodies not lead to inappropriate treatment of the victims' bodies. It is hoped that this article will help those who have the difficult task of managing the dead.

Acknowledgements. Egbert Sondorp, from the London School of Hygiene and Tropical Medicine, provided comments on successive drafts of this paper. The author would also like to thank colleagues at Oxfam and MSF-Spain with whom he has worked in Latin America, India, Africa, and the Balkans.

\section{REFERENCES}

1. de Ville de Goyet C. Maladies transmissibles et surveillance épidémiologique lors de désastres naturels. Bull World Health Organ. 1979; 57(2):153-65.

2. de Ville de Goyet C. Stop propagating disaster myths. Lancet. 2000;356:762-4.

3. Curtis V, Biran A. Dirt, disgust, and disease. Is hygiene in our genes? Perspect Biol Med. 2001;44(1):17-31.

4. Healing TD, Hoffman PN, Young SE. The infectious hazards of human cadavers. Commun Dis Rep CDR Rev. 1995;5(5):R61-8.

5. de Ville de Goyet C. Las enfermedades transmisibles y la vigilancia epidemiológica en situaciones de desastres naturales. Bol Oficina Sanit Panam. 1980;89(4):353-9.

6. Noji EKPH. The public health consequences of disasters. Prehospital Disaster Med. 2000; 15(4):147-57.

7. Pan American Health Organization. Natural disasters. Protecting the public's health. Washington, D.C.: PAHO; 2000.

8. Rischetelli G, Harris J, McCauley L, Gershon RR, Guidotti T. The risk of acquiring hepatitis $\mathrm{B}$ or $\mathrm{C}$ among public safety workers. Am J Prev Med. 2001;20(4):299-306.

9. United States of America, Centers for Disease Control and Prevention. Hepatitis C virus infection among firefighters, emergency medical technicians, and paramedics. MMWR Morb Mortal Wkly Rep. 2000;49(29):660-5.
10. Gershon RR, Vlahov D, Farzadegan H, Alter $\mathrm{MJPH}$. Occupational risk of human immunodeficiency virus, hepatitis B virus, and hepatitis $C$ virus infections among funeral service practitioners in Maryland. Infect Control Hosp Epidemiol. 1995;16(4):194-7.

11. Gershon RR, Vlahov D, Escamilla Cejudo JA, Badawi M, McDiarmid M, Karkashian C, et al. Tuberculosis risk in funeral home employees. J Occup Environ Med. 1998;40(5):497-503.

12. World Health Organization. Hepatitis B. Geneva: WHO; 2000. (Fact Sheet No. 204).

13. World Health Organization. Hepatitis C. Geneva: WHO; 2000. (Fact Sheet No. 164).

14. Joint United Nations Programme on HIV/ AIDS. AIDS epidemic update: 2003. Geneva: UNAIDS; 2003.

15. United States, Centers for Disease Control and Prevention. Guidelines for prevention of transmission of human immunodeficiency virus and hepatitis B virus to health-care and public safety workers. MMWR Morb Mortal Wkly Rep. 1989;38(S-6):3-37.

16. Demiryürek D, Bayramoglu A, Ustaçelebi S. Infective agents in fixed human cadavers: a brief review and suggested guidelines. Anat Rec. 2002;269:194-7.

17. Sterling T, Bishai W, Harrington S, Gershon RR, Chaisson R. Transmission of Mycobacterium tuberculosis from a cadaver to an embalmer. N Engl J Med. 2000;342(4):246-8.
18. McKenna M, Hutton M, Cauthen G, Onorato I. The association between occupation and tuberculosis. Am J Respir Crit Care Med. 1996; 154:587-93.

19. United States, Centers for Disease Control and Prevention. Proportionate mortality from pulmonary tuberculosis associated with occupations-28 states, 1979-1990. MMWR Morb Mortal Wkly Rep. 1995;44(1):14-9.

20. United States, Centers for Disease Control and Prevention. Guidelines for preventing the transmission of Mycobacterium tuberculosis in health-care facilities. MMWR Recomm Rep. 1994;43(RR-13):1-132.

21. Cutter M. In the bag? Nurs Times. 1999;95(20): 55-6.

22. Vass AA, Barshick SA, Sega G, Caton J, Skeen JT, Love JC, et al. Decomposition chemistry of human remains: a new methodology for determining the postmortem interval. J Forensic Sci. 2002;47(3):542-53.

23. Organización Panamericana de la Salud. Terremotos en El Salvador, 2001. Washington, D.C.: OPS; 2002. (Crónicas de Desastres No. 11).

24. Iserson KV. What happens to corpses? Death doesn't have to be a mysterious subject. Emerg Med Serv. 1995;24(6):35-43.

25. Dent BB, Knight MJ. Cemeteries: a special kind of landfill. The context of their sustainable management. In: International Association of Hydrologists. Proceedings of IAH 
Sustainable Solutions Conference, February, 1998. Melbourne: Kenilworth, International Association of Hydrologists; 1998. Pp. 451-6.

26. Mather JD. The attenuation of the organic component of landfill leachate in the unsaturated zone: a review. Q J Eng Geol. 1989;22: 241-6.

27. Üçisik AS, Rushbrook P. The impact of cemeteries on the environment and public health. Copenhagen: WHO Regional Office for Europe; 1998.

28. Reddy KR, Khaleel R, Overcash MR. Behaviour and transport of microbial pathogens and indicator organisms in soils treated with organic wastes. J Environ Q. 1981;10(3):255-66.

29. Pedley S, Howard G. The public health implications of microbiological contamination of groundwater. Q J Eng Geol. 1997;30:179-88.

30. Rodriguez WC 3rd, Bass WMPH. Decomposition of buried bodies and methods that may aid in their location. J Forensic Sci. 1985;30(3): 836-52.

31. Pacheco A, Mendes JMB, Martins T, Hassuda S, Kimmelmann AA. Cemeteries - a potential risk to groundwater. Water Sci Tech. 1991; 24(11):97-104.
32. Spongberg AL, Becks PM. Organic contamination in soils associated with cemeteries. Soil Contam. 2000;9(2):87-97.

33. Spongberg AL, Becks PM. Inorganic soil contamination from cemetery leachate. Water Air Soil Pollut. 2000;117:313-27.

34. Bouwer HY. Groundwater hydrology. New York: McGraw-Hill; 1978.

Manuscript received 7 April 2003. Accepted for publication on 19 March 2004.

RESUMEN Objetivo. Realizar una revisión bibliográfica encaminada a determinar los riesgos de infección que plantean los cadáveres después de un desastre natural, particularmente quiénes corren mayor peligro, qué precauciones se deben tomar y cómo se debe disponer de los cadáveres.

Riesgo de transmisión de enfermedades infecciosas por contacto con cadáveres después de desastres naturales
Métodos. Para que una enfermedad se transmita, es necesario que haya un agente infeccioso, una exposición a dicho agente y un huésped susceptible. Estos son los elementos que se tuvieron en cuenta para calcular el peligro que plantean los cadáveres como fuentes de infección. Se buscaron trabajos sobre el riesgo de infección al que se exponen los trabajadores que velan por la seguridad del público (personal médico de emergencia, bomberos, la policía) y los empleados de casas funerarias, y sobre las pautas observadas para disponer de los cadáveres y prevenir infecciones. También se revisaron unos cuantos trabajos importantes sobre la disposición de los cadáveres y la contaminación de las aguas subterráneas por los cementerios.

Resultados. Las víctimas de desastres naturales suelen morir de traumatismos y raras veces tienen infecciones agudas que puedan producir epidemias. Esto significa que los cadáveres plantean un riesgo sumamente pequeño para el público. No obstante, las personas que entran en contacto cercano con los muertos - el personal militar, el personal de rescate, los trabajadores voluntarios y demás- pueden verse expuestas a fuentes de infecciones crónicas, tales como los virus de las hepatitis B y C, $\mathrm{VIH}$, organismos enteropatógenos y Mycobacterium tuberculosis. Algunas medidas de precaución orientadas a proteger a estas personas son el adiestramiento, el uso de bolsones para los cadáveres y de guantes, las buenas prácticas de higiene y la vacunación contra la hepatitis B y la tuberculosis. Siempre que se pueda, la disposición de los cadáveres debe hacerse de conformidad con las costumbres y prácticas locales. Cuando son muy numerosas las víctimas, el entierro es probablemente el método de disposición más adecuado. Hay muy pocas pruebas de que la contaminación microbiológica del agua subterránea debido al entierro de cadáveres constituya un peligro.

Conclusiones. Es natural que muchas personas, en su afán por protegerse contra las enfermedades, piensen que los cadáveres son fuentes de infección. No obstante, se necesita información precisa sobre los peligros que puedan existir para que las autoridades locales responsables puedan garantizar el manejo adecuado y respetuoso de los cadáveres de las víctimas de desastres naturales. Este trabajo provee información de utilidad para quienes se encuentran en la lamentable posición de tener que manejar dichos cadáveres. 